\title{
Do They -The Maeg Wife and The Maeg Husband- Keep on Loving Each Other Until Now? (305th - 320 Th of Tcheonzamun)
}

\author{
Hyeonhi Regina Park¹, Kunjoo Daegon-Andrea Kim², Jiah Anna Kim³, Alain Hamon4, Rosa Kim5, Sohwa \\ Therese Kim ${ }^{6}$, Sangdeog Augustin $\mathrm{Kim}^{7^{\star}}$ \\ 1Department of Elderly care and welfare, Joongbu University, Kumsan, Republic of Korea (South Korea) \\ 2Department of History, Yonsei University, 50 Yonsei-ro, Sinchon-dong, Seodaemun-gu, Seoul, Republic of Korea (South Korea) \\ 3Department d'Expertise economique, Universite de Paris-Est Creteil, Paris, France \\ ${ }^{4} \mathrm{~L}$ 'Ecole Internationale Jean-Mermoz, Avenue Mermoz, Abidjan, Côte d'Ivoire \\ ${ }^{5}$ Specialite d'Economie politique, Ecole des Hautes Etudes en Sciences Sociales (EHESS), Paris, France \\ ${ }^{6}$ Department of French Language and Literature, Seoul Women's University, 621 Hwarang-ro, Gongneung 2(i)-dong, Nowon-gu, \\ Seoul, Republic of Korea (South Korea) \\ ${ }^{7}$ Department of Companion Animal and Animal Resources Science, Joongbu University, 201 Daehak-no, Chubu-myeon, Kumsan-gun, \\ Chungcheongnam-do, Republic of Korea (South Korea)
}

\section{*Corresponding Author}

Sangdeog Augustin Kim

\section{Article History}

Received: 21.10.2019

Accepted: 30.10 .2019

Published: 06.11.2019

\begin{abstract}
The researchers used the poem of 16 letters of $\left(305^{\text {th }}-320^{\text {th }}\right)$ of Tcheonzamun. They translated the poem with the two different translating methods; one is translation through meaning of Chinese character, and the other is that through the Korean pronunciation of Chinese character. The theme is that "Do they -the Maeg wife and the Maeg husband- keep on loving each other until now?"
\end{abstract}

Keywords: The poem of 16 letters of $\left(305^{\text {th }}-320^{\text {th }}\right)$, Tcheonzamun, the Korean pronunciation of Chinese character, the Maeg wife and the Maeg husband.

\section{INTRODUCTION}

In the next part, the word concerning 'irreligious population' occurred [1]; "Go preach the gospel." The ordinary methods of Legion visitation will be followed, the underlying idea being the effort to establish relations of true friendship with the persons visited. That gained, almost everything is gained."

On reading this part, Augustin - one of the authors- thought that they had better decide the title of the poem $\left(305^{\text {th }}-320^{\text {th }}\right)$ of Tcheonzamun as follows; 'The wife and the husband who do not love each other any more.' It is pitiful if the couple does not look themselves favorably. They, the husband and wife, have loved together, and they succeeded in their marriage. However, the present researchers have surprisingly met the happening of the couple on the Korean translation of this poem of Tcheonzamun (The thousand character essay). It is same as the previous part concerning 'irreligious population.' "I loved my husband, but he departed from me!" Why did the husband do so? What is the reason of this occurrence? Did he love her wife, but he was forced to leave her wife? Or did he not like her wife, and he came out of the home with her wife? Dallet [2] wrote that the origin of Korean people is Tartar. Chung [3] wrote that there was a tribe, whose name is Sanyung or Maeg. Zhang [4] described Maeg tribe in a very good view-point. The researchers thought that Tcheonzamun was written by Maeg people [5]. Therefore the researchers added an adjective before the words of 'the wife and the husband' as 'Maeg wife and Maeg husband'. It is continued as follows; "Do they -the Maeg wife and the Maeg husband- keep on loving each other until now?" The reader will find the answer if she (he) reads both the translation through Korean pronunciation and that through the meaning of the Chinese character.

Copyright @ 2019: This is an open-access article distributed under the terms of the Creative Commons Attribution license which permits unrestricted use, distribution, and reproduction in any medium for non commercial use (NonCommercial, or CC-BY-NC) provided the original author and source are credited. 


\section{Materials ANd Methods}

The researchers used the poem of 16 letters of $\left(305^{\text {th }}-320^{\text {th }}\right)$ of Tcheonzamun. They translated the poem with the two different translating methods; one is translation through meaning of Chinese character, and the other is that through the Korean pronunciation of Chinese character.

\section{RESULTS AND Discussion}

The presenting researchers used the poem of $\left(305^{\text {th }}-320^{\text {th }}\right)$ of Tcheonzamun with the two different translating methods. The first is translation through meaning of Chinese character, and the second is that through the Korean pronunciation of Chinese character.

At first, the researchers translated the poem through the meaning of Chinese character.

The order in Tcheonzamun/ Korean pronunciation of Chinese character in English alphabet/ Chinese character/ Translation through the meaning of Chinese character in English

305-308 Hag-Woo-Deung-Sa 學 優 登 仕 If you want a brilliant man (woman)(優) to study well(學), you must treat(登) the man(the woman) in a good manner(仕).

309-312 Seob-Zig-Zong-Zeong 攝職從政 No, it is not true. If you want somebody to handle (攝) the spear well and somebody to listen the voice of the music (職) (In other words, if you want someone to be grown up well), you must be able to reprove (從) the man (the woman) once or twice(政).

313-316 Zon-I-Kam-Dang 存 以甘棠 If you want that the favourable thing (以) remained (存) in your life, you must think the sour thing(棠) as the sweet one(甘).

317-320 Keo-I-lk-Yeong 去而益詠 If you want to remove (去) this good thing (而) from your life. Speak in a loud voice (詠)! Fight each other! And then, you will reach such a bad condition (益).

Our Lord Jesus of the two people -Hyeonhi and Augustin-, thank you amen!

"With the thing in my heart" on the Gospel of Luke.

Our Lord! Saint Mary and Saint Joseph amen!

It is a theme. "If there is a difficult thing for you (Seob-Zig-Zong-Zeong 攝職從政), you have to endure such a hard condition (Zon-I-Kam-Dang 存以甘棠)!

This poem concerns about the happenings between the husband and the wife.

Our Lord Jesus, thank you amen!

At second, the researchers translated the poem through the Korean pronunciation of Chinese character.

The order in Tcheonzamun/ Korean pronunciation of Chinese character in English alphabet/ Chinese character/ modified Korean pronunciation of the Chinese character in English alphabet(modified Korean pronunciation of the Chinese character in Korean alphabet)/ Translation through Korean pronunciation and written in English

305-308 Hag-Woo-Deung-Sa 學優登仕 Ae-gu-Deung-ssal!(애구 등쌀!) I don't know well, but any way I do like my husband very well!

309-312 Seob-Zig-Zong-Zeong 攝職從政 Seob-zi-Zong-Zong!(섧지 종종!) I often feel sorrowful!

313-316 Zon-I-Kam-Dang 存以甘棠 Zoneu-ni-Kan-dae!(좋으니 간대!) I have felt the deep love to my husband, but he wants to leave me! 
317-320 Keo-I-Ik-Yeong 去而益詠 Ggeo-i-i-Eong!(꺼이이 엉!) I weep with the sorrow voice of 'Ggeo-i-i-Eong!' and misses him.

This Tcheonzamun poem ( $305^{\text {th }}-320^{\text {th }}$ letters) expresses the deep feeling of the young Maeg wife, who loves her husband

As a conclusion, this Tcheonzamun poem is not a song of 'The wife and the husband who do not love each other any more', this song is but 'They -the Maeg wife and the Maeg husband- keep on loving each other until now.'

\section{ACKNOWLEDGEMENTS}

We thank Mr Ilsoo Joseph Kim and Mrs Bohwa Kim, Mr Yeonghag Park and Mrs Hilye Sarah Kim. We thank Father Jean Blanc and Father Hifumi Iwazaki. We thank Mrs Tamako Hayashi and Mr Yoshihiro Hayashi, Professor Francine Tenaillon and Professor Nicolas Tenaillon, Miss Okja Kim, Mr Hwansik Park. We thank the students of Department of Companion Animal and Animal Resources Science in Joongbu University and the members of Daejeon Ludovich of Ordo Franciscanus Saecularis (OFS).

\section{REFERENCES}

1. Mariae, C. L. (2005). The official handbook of the Legion of Mary (Revised edition). Dublin. Ireland. 319-322.

2. Dallet, C. H. (1874). Histoire de l'Eglise de Coree (History of Korean Catholic Church). Victor Palme. Paris. France. 11-99.

3. Chung, I. B. (2012). Choseonsa Yeonku (Study of Korean History) vol. 1 (Edited by SJ Moon). Korea History Foundation, Seoul. 254-262.

4. Zhang, S. N. (1716). Kangxizidian. (Edited by Zhonghua Book Company in 2013), Beijing.

5. Park, H.R., Kim,J.A., Kim, K.D.A., Kim, J.A., Kim, S.T., Kim, R., Hamon, A., Kim, S.A.. (2017). Ancient Koreans petition to God in Tcheonzamun: The thousand character essay poem (641st to 656th letters). Journal of Languages and Culture, 8(6), 79-84. 